\title{
Understanding the Current State and Future Directions of Hotel Sector Knowledge Management: A Literature Review
}

\author{
Christoph Voegeli \\ Bangladesh University of Professionals, Dhaka, Bangladesh \\ E-mail: manager4hotel@gmail.com
}

Received: February 2, 2019 Accepted: February 22, 2019 Published: May 13, 2019

doi:10.5296/ber.v9i2.14778

URL: https://doi.org/10.5296/ber.v9i2.14778

\begin{abstract}
This review highlights the huge opportunity provided by leveraging knowledge management principles across the hotel industry. By way of context, the author has over 20 years of international experience in the hotel industry (at executive level, including managing privately-owned and single hotels, some as part of a medium-sized brand, with others as part of a very large [global] hotel brand). When he transitioned from a hotel company of medium size to one of the largest (about 10 years ago), he observed significant differences in business processes, structure, resources, and culture. Wondering about these differences, he examined them more closely and started to read broadly about strategy, competitive advantages, and capabilities. Gaining a deeper understanding, he realized that the observed differences were related to knowledge management.

In his research, many organizations were found to have used knowledge management to extract, recycle, harness, share, and leverage knowledge for improved performance and competitive advantage. In some cases, millions of US dollars were saved. Furthermore, from knowledge management practices in consultancy, healthcare, and manufacturing, the expectation was that rich, in-depth research would be found on hotel-(specific) knowledge management. Logically, it was expected that top executives (and other stakeholders holding hotel portfolios, such as real estate/investment funds/investment bankers and hotel operators) would be extremely keen to learn about and use knowledge management to leverage their companies' performance. Surprisingly, the opposite seems to be the case. This thorough review demonstrates that little research has been conducted on hotel knowledge management, and that even in hotel-(specific) knowledge management, "secrecy" (operating in a vacuum) can be experienced. The premise is that top executives (C-level executives) constantly search for the latest insights (knowledge) and best practices to find implementable concepts so their
\end{abstract}


organizations can remain ahead of the competition. This paper reviews and establishes the current state of the existing body of hotel-(specific) knowledge management literature and highlights gaps and possible opportunities for the future. Through adding to the depth of hotel-(specific) knowledge management research, refreshed interest can be generated in this field, possibly stimulating a better understanding of how hotel-(specific) knowledge management can be used to maximize its benefits.

Keywords: Literature review, Hotel knowledge management, Research quality, Knowledge management benefits

\section{Introduction}

The hotel sector today is a very competitive environment. Changing demographics and guests' demands for better deals, new and exciting experiences, and tailored services all require industry operators to provide a superior guest experience. Hotel company (mega) mergers and takeovers all complicate the industry and the flow of knowledge in hotels and between hotels in branded chains. In 2018 alone, 18 significant mergers and acquisitions were reported by Ricca (2018).

The demand for management tools to simplify this complexity and add value is high. Complementing popular management tools, such as benchmarking, total quality management (TQM), the balanced scorecard (BSC), and supply chain management (SCM), knowledge management (KM) has become an important and highly regarded tool in several industries. However, despite the extensive body of research in the field of KM, much less research has been carried out in the hotel sector-specific KM domain. After omitting studies with a wider scope, for example, tourism and hospitality, this review of the literature over the past 20 years found that only the four papers discussed below had a hotel-specific KM focus (the most recently published between 2008 and 2014), with this assessment based on the paper's title. Some papers considered specific aspects of KM (e.g., knowledge sharing) rather than integrated (holistic) KM systems (Hallin \& Marnburg, 2008; Hu, Horng, \& Sun, 2009; Sigala \& Chalkiti, 2007; Yang, 2007, 2009, 2010; Yang \& Wan, 2004). The current research therefore attempted to discover whether comprehensive (advanced/integrated) hotel-(specific) knowledge management (HKM) programs were to be found in the current literature of multinational hotel companies. An extension to this research was to determine if such HKM implementation was successful and what its impact was on hotel companies.

Despite a strong and steady stream of research in the general KM domain, HKM research is sparse, disconnected and not focused. Furthermore, past research has not explored KM in multinational hotel companies on a global level and in a holistic way. For example, no detailed research has been conducted to determine which KM programs or models are used, how they have evolved over time, and whether hotel companies share and exchange their KM experiences. Filling this gap could greatly benefit hotel companies. According to Voegeli (2015):

Knowing that major hotel companies generate yearly revenues of about USD 5-10 billion globally and assuming an improvement of $20 \%$, the staggering value at stake is an 
enhancement of USD 2 billion. That is serious business.

Hence, it is understandable that the use of KM in the global hotel industry - as in other industries - could mean hundreds of billions of dollars in improved profit.

Unsurprisingly, this view is supported by a case study (Frantz et al., 2000) which reported that the Ritz Carlton had the best knowledge program and the only study about HKM in the 1990s. This hotel company detailed its KM practices in fulfillment of the Malcolm Baldrige Award requirements. Reference is made in the case study to the increase in operational effectiveness and the tremendous performance improvement (the 1995 pre-tax return on investment was 5.3\%, whereas in 2000 it had increased to 17.6\%) (Frantz et al., 2000, p. 27). This, by itself, was a very significant achievement. Moreover, in benchmarking financial performance against other brands (direct competitors in the luxury hotel segment), the Ritz Carlton was found to consistently outperform all other hotel companies. What would be very interesting to know today is whether the KM program (part of the Malcolm Baldrige Award requirements) has been maintained, improved, replaced or integrated, or if KM has even been dropped altogether. This juncture is where this paper's author sees the research gap and the current study's value.

Researching the HKM field will highlight its current state and the possible gaps. Identifying these gaps will inform a new research agenda (focus) to advance HKM knowledge. Ultimately, it is hoped that HKM can be re-energized, leading to new higher levels of HKM knowledge and capability that will add value to the hotel industry.

Against this backdrop, the problem statement, as described next, is investigated. The primary aim is to understand and analyze the current state of HKM by reviewing the most recent and relevant literature. The secondary objective is to determine if advanced (integrated/detailed) HKM programs are available and if multinational hotel companies use these programs for improved performance.

Moreover, keeping the above-mentioned research aim and secondary objective in mind, the specific objectives of the current study are as follows:

a) To review the most recent literature to find out whether certain trends are present in hotel sector-specific KM.

b) To compare the recent hotel sector-specific KM literature and analyze whether similarities, patterns, or overlaps are evident.

c) To investigate whether research and industry utilization are advancing with a unified focus.

The hotel industry is a major economic sector with its global market size of just over US $\$ 570$ billion (Statista, 2017). It represents hundreds of billions of US dollars in real estate value and provides employment for millions of people and their dependents. It is believed that leaders in this sector should have an extremely keen interest in using HKM to drive this industry forward. 


\section{Literature Review}

The literature review is organized to initially provide a wider overview of the KM literature in order to understand KM's general development and evolution. An analysis is then undertaken of the most recent KM research to see where KM is currently standing. The third part involves drawing comparisons and conducting analysis to identify possible gaps, overlaps, and divergence from what constitutes KM's core (see Figure 1).

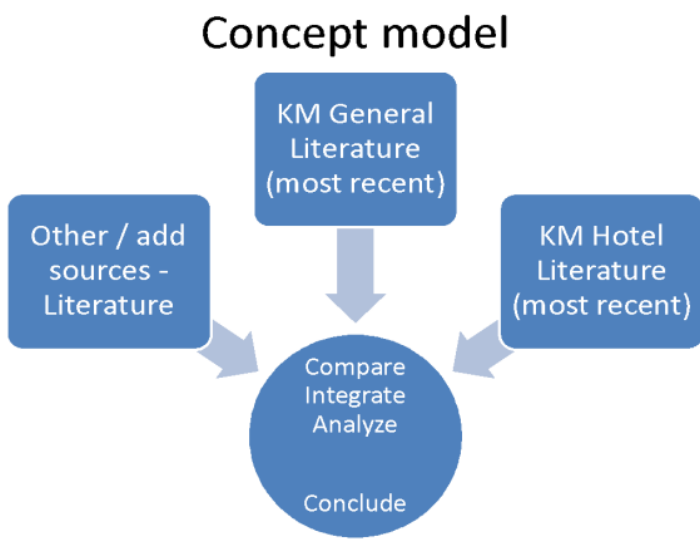

Figure 1. Sources of Research and Insights Informing this Study

Peter F. Drucker (2001), one of the early management experts, forecast that society and the economy would depend more and more on knowledge. From this idea, KM grew in popularity over the next 20-30 years. Both Drucker (2001) and Gold, Malhotra, and Segars (2001) referred to a change in society (with implications for the business environment). While Drucker (2001) suggested that knowledge would become a key resource (for knowledge workers), Gold et al. (2001) likewise highlighted the point that knowledge and knowledge assets would have a great impact as, through their use, companies would thus realize economic value. Lambe (2011) placed the beginnings of KM even earlier. He referred to Fritz Machlup (1962) who, in his work and publications, had already projected the basic idea of KM, and to Kenneth J. Arrow $(1962,1969$, 1974) who, in the 1960s and 1970s, had published research that influenced KM in the organizational setting.

\subsection{Complexity and Diversity of the Knowledge Management (KM) Domain}

Knowledge management (KM) relates to, and is built on, a wide range of concepts and interdependent complex disciplines. According to Dalkir and Liebowitz (2011), this includes: organizational science; cognitive science; linguistics and computational linguistics; information technologies (e.g., knowledge-based systems, document and information management, electronic performance support systems, and database technologies); information and library science; technical writing and journalism; anthropology and sociology; education and training; storytelling and communication studies; and collaborative technologies (e.g., computer-supported collaborative work [CSCW], groupware, intranets, extranets, portals, and other web-based technologies).

This extensive list indicates that KM is a management tool with much complexity, scope, and 
depth. This also makes KM difficult to (fully) understand and hard to (successfully) implement. It is more like a philosophy which, according to the KM hierarchy (Duru, 2014), comprises data; information; knowledge; wisdom; and enlightenment. It is more a set of experiences and practices that need to be learned, practiced, understood, spread, and maintained to generate value.

\subsection{What is Knowledge?}

According to a Merriam Webster online dictionary, the term "knowledge" is defined as information, understanding, or skill gained from experience or education. This general usage definition has been interpreted in various ways by different professionals in different cultures.

In addition to the overall understanding, the term "knowledge" has subdivisions as explained in the four categories below (adapted from Blumentritt \& Johnston, 1999):

(a) Codified knowledge (e.g., catalogue [Millar, Demaid, \& Quintas, 1997] or symbolic knowledge [Collins, 1993]) which is concerned with the information made available (by printing or publishing)

(b) Common knowledge (e.g., informal [Fleck, 1997] or embedded knowledge [Blackler, 1995]) which relates to routines and practices

(c) Social knowledge (e.g., social [Millar et al., 1997] or encultured knowledge [Blackler, 1995; Fleck, 1997]) which refers to relationships and cultural aspects

(d) Embodied knowledge (e.g., embodied knowledge [Blackler, 1995; Collins, 1993], know-how [Lundvall, 1996], or process knowledge [Millar et al., 1997]) which could also be called "tacit knowledge" (competencies).

Categorizing knowledge enables people to think about it from different perspectives, but any categorizing approach inevitably has some limitations. Knowledge without a context is somewhat meaningless. However, knowledge within a context, such as how to improve hotel industry performance, has great value and creates opportunities. The literature shows that knowledge has been effectively shared across industries to create learning and value. However, the current review highlights that this has not yet happened in the hotel industry.

\subsection{Knowledge Management (KM) Definitions}

To gain a better understanding of the many ways in which KM is defined, a two-step review was applied. Firstly, definitions from 12 highly regarded KM scholars were listed (Table 1), with the definitions then reviewed with the help of a word cloud generator tool. Secondly, the elements of several KM models proposed by scholars were compared. 
Table 1. Commonly adopted definitions of knowledge management (KM)

\begin{tabular}{|c|c|}
\hline Author/s & Definition \\
\hline Petrash (1996) & $\begin{array}{l}\text { Getting the right knowledge to the right people at the right time so they can make the } \\
\text { best decision. }\end{array}$ \\
\hline Bassi (1997) & $\begin{array}{l}\text { The process of creating, capturing, and using knowledge to enhance organizational } \\
\text { performance. }\end{array}$ \\
\hline Hibbard (1997) & $\begin{array}{l}\text { The process of capturing a company's collective expertise wherever it resides: in } \\
\text { databases, on paper, in people's heads - and distributing it to wherever it can help } \\
\text { produce the biggest payoff. }\end{array}$ \\
\hline Duhon (1998) & $\begin{array}{l}\text { "A combination of technology supporting a strategy for sharing and using both the brain } \\
\text { power resident within an organization's employees and internal and external } \\
\text { information found in 'information containers' (primarily documents). The goal of KM } \\
\text { is to simultaneously manage data, information, and explicit knowledge while leveraging } \\
\text { the information resident in people's heads (tacit knowledge) through a combination of } \\
\text { technology and management practices" (p. 9). }\end{array}$ \\
\hline Wiig (1997a, 1997b) & $\begin{array}{l}\text { The objectives of KM are "(a) to make the enterprise act as intelligently as possible to } \\
\text { secure its viability and overall success, and (b) to otherwise realize the best value of its } \\
\text { knowledge assets" (p. l). }\end{array}$ \\
\hline Knapp (1998) & $\begin{array}{l}\text { "A set of processes for transferring intellectual capital (IC) to value processes such as } \\
\text { innovation and knowledge creation, knowledge acquisition, organization, application, } \\
\text { sharing, and replenishment" (p. 3). }\end{array}$ \\
\hline $\begin{array}{l}\text { Liebowitz and Wilcox } \\
\text { (1997) }\end{array}$ & $\begin{array}{l}\text { The "ability of organizations to manage, store, value, and distribute knowledge" } \\
\text { (Preface). }\end{array}$ \\
\hline $\begin{array}{l}\text { O’Dell and Grayson } \\
(1998)\end{array}$ & $\begin{array}{l}\text { A conscious strategy of getting the right knowledge to the right people at the right time } \\
\text { and helping people share and put information into action in ways that strive to improve } \\
\text { organizational performance. }\end{array}$ \\
\hline $\begin{array}{ll}\text { Liebowitz } & \text { and } \\
\text { Beckman (1998) }\end{array}$ & $\begin{array}{l}\text { The formalization of and access to experience, knowledge and expertise that create new } \\
\text { capabilities, enable superior performance, encourage innovation, and enhance customer } \\
\text { value. }\end{array}$ \\
\hline $\begin{array}{l}\text { Abel and Oxbrow } \\
(2001)\end{array}$ & $\begin{array}{l}\text { "The creation and subsequent management of an environment that encourages } \\
\text { knowledge to be created, shared, learnt [sic], enhanced, organized, and utilized for the } \\
\text { benefit of the organization and its customers." }\end{array}$ \\
\hline $\begin{array}{l}\text { Gray Southon, Todd, } \\
\text { and Seneque (2002) }\end{array}$ & $\begin{array}{l}\text { "KM practices are tools and approaches used to improve individuals' ability to access } \\
\text { knowledge that is held by others in an organization" (p. 10). }\end{array}$ \\
\hline Shelley (2007) & $\begin{array}{l}\text { Leveraging, socializing and applying intellectual assets in context to co-create (mutual } \\
\& \text { sustainable) value, stimulate learning and build capability. }\end{array}$ \\
\hline $\begin{array}{l}\text { International } \\
\text { Organization } \quad \text { for } \\
\text { Standardization (ISO) } \\
\text { (2019) }\end{array}$ & The management of knowledge. \\
\hline
\end{tabular}

To highlight the strongest themes in these definitions, the words were uploaded to a word cloud generator tool (Wordclouds.com). This tool computes text/documents and counts 


\section{Al Macrothink Institute ${ }^{\mathrm{TM}}$}

repetitions of words, turning them into a word cloud for better visualization. The words used most frequently are large, while those used less frequently are smaller. The result in Figure 2 shows the prominence of the following words: knowledge, information, right (related to time and people), value, organization, people, and performance.

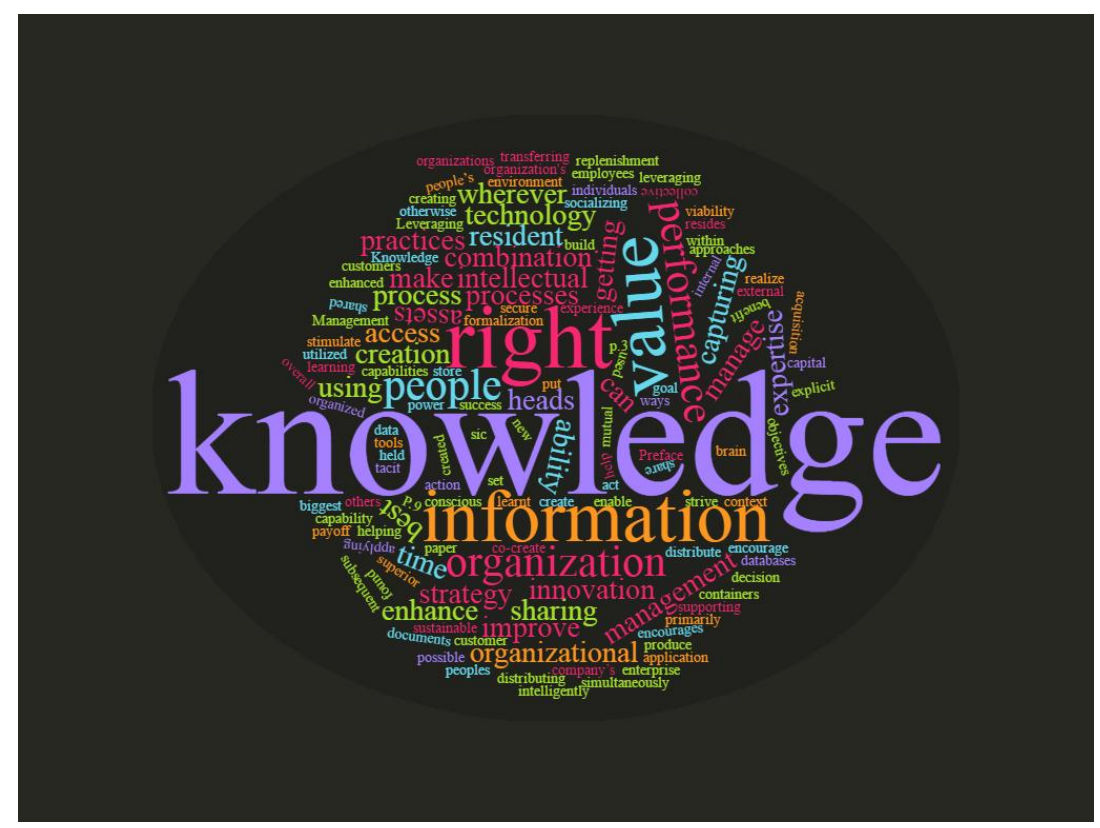

Figure 2. Word Cloud Application to KM Definitions

Through this visualization, knowledge and information are shown to be the foremost topics in the KM domain. However, the terms "knowledge" and "information" are often used interchangeably (with people confused about or unaware of their respective meanings as information is more widely considered to be organized data, whereas knowledge is regarded as a property of people) (International Organization for Standardization [ISO], 2019). Experienced knowledge practitioners consider knowledge to comprise people's understanding of how to act on that information. Information is data in context, but data on their own (i.e., without context) are less useful, because what they relate to is unclear. For example, I see the following numbers $0,5,6$ and 7 but cannot understand their meaning. However, if I see the same numbers in the context of the currency exchange rate-76.50 Bangladeshi taka (BDT) per US\$1 - the meaning of the data becomes clear. The many arguments about the boundaries between data, information, knowledge, and wisdom have been well summarized by Williams (2014, 2015).

\subsection{What is a Knowledge Hierarchy (Pyramid)?}

Davenport and Prusak (1998) identified three layers (i.e., data, information, and knowledge) for how organizations manage knowledge. This basic model appears to have persisted to the present day with more refinement over time. From Davenport and Prusak's (1998) quite simple (three-layer) pyramid to Dalkir and Liebowitz's (2011) work, the key concept (data, information, and knowledge) has remained unchanged, although it has been added to by some authors. This model (as shown in Table 2) is widely debated and often challenged by KM professionals. 
Table 2. Knowledge (dimensions) hierarchy (pyramid)

\begin{tabular}{|l|l|l|}
\hline Davenport and Prusak (1998) & Magnier-Watanabe and Senoo (2008) & Duru (2014) \\
\hline & & Enlightenment \\
\hline & Wisdom & Wisdom \\
\hline Knowledge & Action/Reflection & Knowledge \\
\hline Information & Information & Information \\
\hline Data & Data & Data \\
\hline
\end{tabular}

Based on Table 2, organizations need to collect (extract) data, put data into context (make sense of data), and turn data into (usable, i.e., required) knowledge, or alternatively leverage information to co-create new knowledge (Shelley, 2017). Although the conversion of information into knowledge is a controversial concept, for information to be effectively used in decision making requires the application of knowledge. Sustained high performance is the result of applying knowledge assets to consistently achieve process improvement and competitive advantage which ultimately propel performance to the level of mastery (wisdom/enlightenment) (Ihrig \& MacMillan, 2015).

\section{Evolution of the Knowledge Management (KM) Literature}

As with any information or research knowledge, it is important to evaluate its strength and importance to evaluate its applicability. This section looks more closely at KM evolution from the perspectives of several scholars. Serenko (2013) suggested that KM can be segregated into three phases:

\section{First phase (prior to mid-1990s)}

- Techno-centric view of knowledge processes

- Existence of a priori knowledge in organizations

- Emphasis on "best practices" and "lessons learned"

- Focus on explicit knowledge codification and storage

- A person is recognized as a source of knowledge

- Knowledge-sharing processes are initiated and driven by management

- Search for "true knowledge"

\section{Second phase (mid-1990s-early 2000s)}

- Importance of human factors and tacit-explicit knowledge conversion

- Accumulation of human and intellectual capital within an organization

- Role of social and cultural aspects in organizational learning

- Focus on bundled knowledge resources of an organization rather than on an individual possessing knowledge 
- Search for "applied knowledge"

- Knowledge-sharing processes are initiated and driven by individual employees as part of their daily routine

Third phase (early 2000s-2013)

- $\quad$ Strategic perspective

- Reconciliation of human- and techno-centric views on knowledge creation, sharing, and storage

- Identification, development, and support of autonomous, informal, and self-managed social networks

- Increasing importance of cultural and contextual aspects

- Collaborative KM

- Leveraging collective knowledge

- Societal learning, the democratization of knowledge, and citizen involvement

- Ethical social innovation impact on individuals, organizations, and society

- Managing knowledge as a flow

- Focus on value creation

As shown in Figure 3, Dixon (2012) proposed three eras of KM, with similarities between these eras and Serenko's (2013) three phases described above. Dixon's eras highlighted how the level of maturity of $\mathrm{KM}$ thinking has evolved throughout the years, how $\mathrm{KM}$ is implemented, and how the KM benefits have changed as organizations have improved their KM approach. 


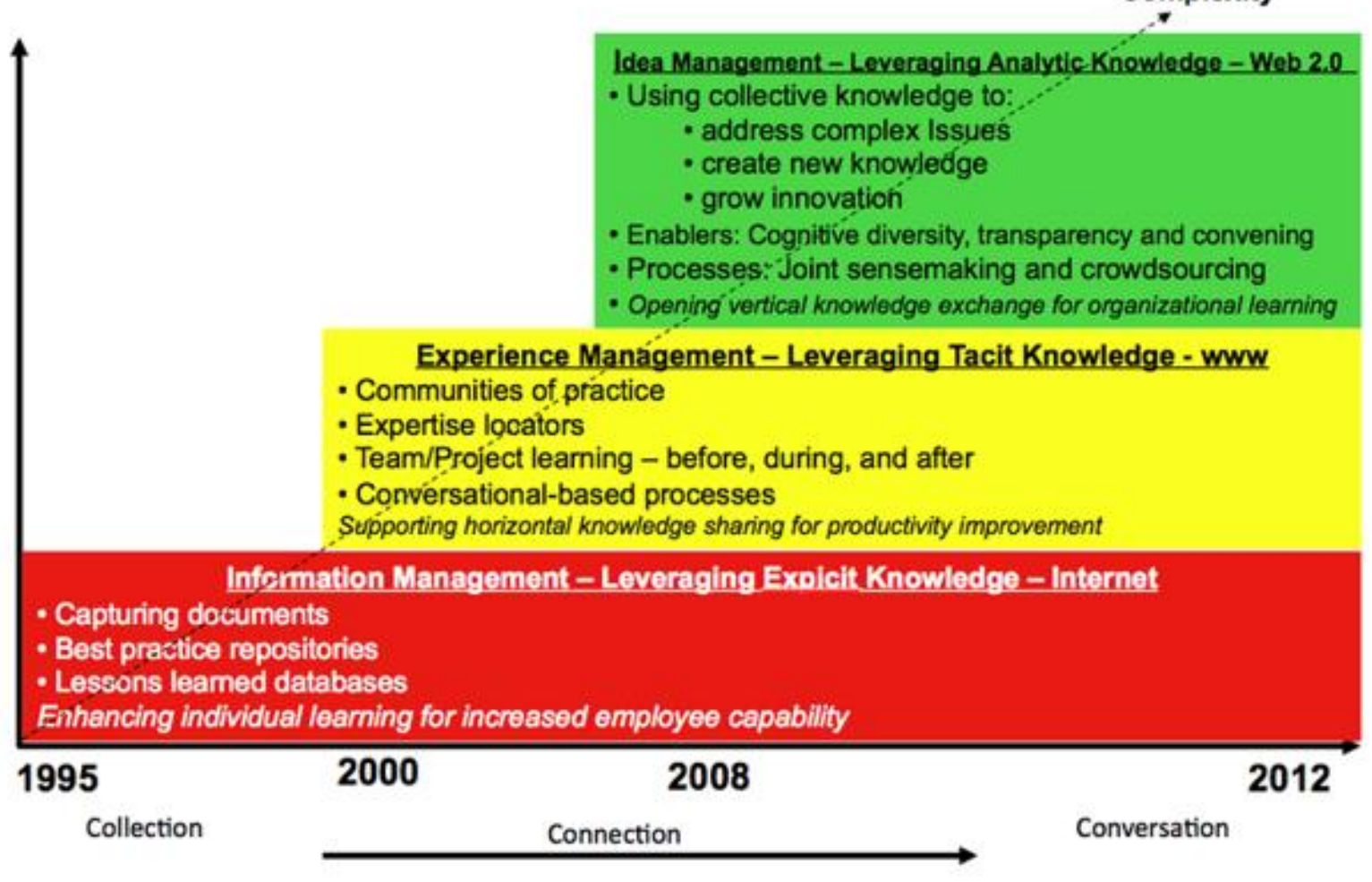

Figure 3. Three Eras of KM (Dixon, 2012)

Figure 3 shows how the complexity of, and disparity in, the dimensions of KM have changed over the three KM eras. Broadly speaking, the congruence is apparent as both Serenko (2013) and Dixon (2012) have divided KM evolution into three phases (before mid-1990s, mid-1990s-early 2000s, and early 2000s-2013). However, when we look at the dimensions in each phase, divergence becomes evident. Whereas Serenko (2013) and Dixon (2012) have some overlap in each era (e.g., in the early phase: lessons learned, best practice, and focused on explicit knowledge), significant differences also emerge. For example, in the third era, only one aspect is shared. Nonetheless, as in any evolution, the overall development is steadily progressing from simple beginnings to greater complexity and refinement of the concept (process). From a wider perspective, it can be said that the first phase was the discovery that companies had knowledge assets ("obvious": explicit knowledge ... competencies, skills, best practice ... etc.) that were untapped. Once these assets were identified, companies began to understand, collect, store, and reuse them to generate more value.

During the second phase, KM was refined with greater understanding that:

- competencies were needed to identify and leverage tacit knowledge;

- new tools (communities of practice) were added; and

- the importance of socialization and culture was recognized and integrated with KM efforts.

Surprisingly, in the last phase, Dixon (2012) seemed to have a more novel concept of KM 
(Web 2.0: address complex issues, create new knowledge), whereas Serenko (2013) argued for the strategic perspective and dimensions such as a socialization culture. The increase in collaboration is familiar as it was part of the second phase. More recently, the focus of the leading thinking in knowledge disciplines has been on the co-creation of new knowledge in real time and usually in the context of projects (Shelley, 2017).

\section{Important Knowledge Management (KM) Concepts}

\subsection{Tacit and Explicit Knowledge}

We know more than we can tell (Polanyi, 1966, p. 4).

Tacit knowledge, in a very simplistic way, could be described as "hidden or below the surface knowledge" including what is able to be processed in people's heads. It is when people find it very hard to explain a process or activity (what/how something is done). It is, in fact, the most common routine (habitual) work which people have the greatest difficulty in explaining. For instance, if you ask a housewife who has just taken a cheesecake from the oven about the precise process and steps for baking the cheesecake, you will most likely find that she will struggle to correctly explain the entire process (ingredients, steps like preheating, sifting, measuring, mixing, baking temperature, timing ... etc.) in sequence. However, this "hidden knowledge" is of great value (potential) to companies, for example, this well-known British Petroleum (BP) case:

A BP exploration geologist located off the coast of Norway discovered a more efficient way of locating oil on the Atlantic seabed in 1999 ... The employee posted a description of the new process on BP's intranet ... Within 24 hours, another BP engineer working on a well near Trinidad found the posting and emailed the Norwegian employee for additional details ... the Trinidad team successfully saved 5 days of drilling - amounting to US\$600,000 [savings] (Becerra-Fernandez \& Sabherwal, 2014, p. 81).

This exemplifies the potential of tacit knowledge and why companies (leadership) should be very concerned and serious about extracting and making knowledge available for the whole organization. They may even decide to externalize KM (e.g., sharing with a supplier/partner to develop or innovate technology or services).

\subsection{Communities of Practice}

In the late 1990s, Lave (1991) and Wenger (1998) coined the term "communities of practice (COPs)" as a model of situated learning and engaged (group/community) learning. The term was explained as follows: "communities of practice are groups of people who share a concern or a passion for something they do and learn how to do it better as they interact regularly." This concept is based on two observations:

1) a group of people can draw on more knowledge (brain power) than a single person

2) an idea can be discussed (bounced off) and reflected within the group which usually results in a better solution (outcome).

As with other concepts, the COP concept has become an integral part of KM and its practices. 
In fact, it is also widely used in non-KM environments where teams (e.g., a company's development team or a team of university students) seek to generate better outcomes by working (thinking) and solving problems together.

\subsection{Socialization, Externalization, Combination, and Internalization (SECI) Concept}

In 1991, Nonaka (1991) created the model of "knowledge creation" known as the SECI (socialization, externalization, combination, and internalization) concept, which describes the ways in which knowledge is generated, transferred, and re-created in organizations. The model uses the following steps:

- Two forms of knowledge (tacit and explicit)

- An interaction dynamic (transfer)

- Three levels of social aggregation (individual, group, and context)

- Four "knowledge-creating" processes (socialization, externalization, combination, and internalization.

As the originator of this concept was a Japanese scholar, it was naturally first applied in Japanese factories (automobile manufacturing) but it later successfully spread to other continents and industry sectors.

\subsection{Knowledge Management (KM) Frameworks}

Since the early days of KM, many scholars have attempted to create a framework that would help to improve the structure and understanding of KM activities (Lambe, 2011; Shelley, 2009; Williams, 2014, 2015). The first concept was Wiig's (1993) widely respected three-pillar model which subsequently experienced evolution and succession through the work of later KM scholars. All models varied in approach, and in their levels of integration and complexity (e.g., Arthur Andersen Business Consulting \& American Productivity and Quality Center (APQC), 1996; Cawthorne, 2009; Choo, 1996; Heisig, 2005, as cited in Heisig, 2009; Jashapara, 2005; Leonard-Barton, 1995; Pawlowski \& Bick, 2012; Petrash, 1996). In addition to the usual evolution from an initial simple concept to a more integrated and complex one, the KM framework incorporated new (external/additional) factors (e.g., globalization). The most recent and most highly integrated but also most complex framework is Pawlowski and Bick's (2012) global knowledge management framework (GKMF). This framework combines and integrates the work of the European Committee for Standardization (CEN) (2004); Heisig (2009); and Maier (2007, cited in Maier \& Schmidt, 2007).

Interestingly, in comparing the KM frameworks that emerged in the last 10-15 years, certain patterns and parallels are evident. Firstly, more recent concepts have placed KM in the center, in a similar way to being at the center of a galaxy orbited by stars, interstellar gas, dust, and black matter. For example, in Jashapara's (2005) model, KM (in the center) was encircled by strategy; system and technology; organization learning; and culture. Each sphere had dimensions/extensions (e.g., culture with implementation and change management) added to the four core elements. Cawthorne's (2009) later model had some similarity to that of 
Jashapara (2005) with the dimensions, organizational learning, and systems and technology being very similar to Cawthorne's (2009) information and communications technology (ICT). However, in Cawthorne's (2009) model, human resources management (HRM) and information management were added and clustered around those four circular spheres, indicating the tools and capabilities that would make KM work. Moreover, further integration and evolution pushed the boundaries and resulted in the global KM framework. One important aspect for multinational companies is globalization as it adds the global (cross-cultural) dimension. While this significantly increases the complexity of implementing and maintaining knowledge across sectors, at the same time, opportunities can arise as a result of the diverse knowledge sources and possible divergent views that encourage different (innovative) solutions.

The work of Pawlowski and Bick (2012) addressed the need to develop an integrated and unified model. These authors understood the necessity of using a high-level approach (i.e., a KM program's structure and architecture for a global firm is somewhat different to a KM program - or a KM initiative - of a single business unit). However, even with the complexity and wider context of such a model, Pawlowski and Bick's (2012) model looks rather static (technocratic), thus making it clumsy and harder to understand.

It can be argued that the layout does not reflect KM's natural cascading (hierarchical) process. Rearranging the layout in the manner shown in Figure 4 (top down, as suggested by the current paper's author) may have merit.

\begin{tabular}{|c|}
\hline $\begin{array}{c}\text { Leadership (supported/flanked by infrastructure and } \\
\text { takeholders) }\end{array}$ \\
\hline Strategy \\
\hline Culture \\
\hline Instruments (human, technological) \\
\hline Knowledge (resources/problems) \\
\hline Result/outcome (performance, knowledge) \\
\hline
\end{tabular}

Figure 4. Proposed KM Framework Layout

Source: author of paper

However, as with any paradigm, the mapped process (concept) and actual real-life implementation are not the same. The human factor should not be underestimated. If we compare the GKMF to a car engine, we find that both represent complex systems comprising connected parts that work (move) together as a whole and produce an output (for the GKMF, knowledge; for a car engine, power). However, without lubrication, neither system will work. Just as oil lubricates a car engine so that it runs smoothly (with the least amount of friction/loss), with KM as the engine, the oil flowing through the (company) system is the soft (human) component that can make the company work well (or, on the other hand, cause friction, making the company work harder and more inefficiently—see Figure 5). 


\section{Macrothink}

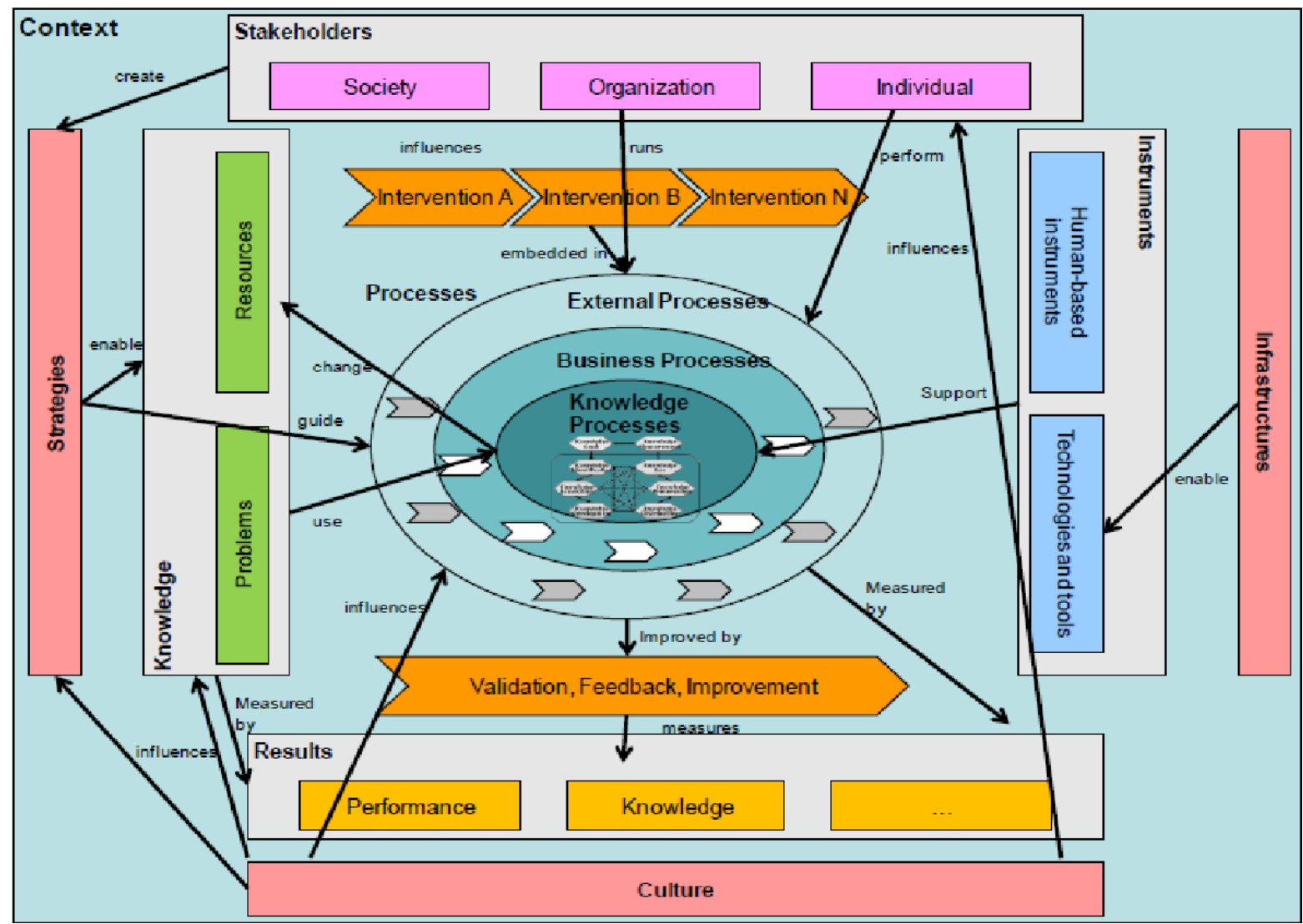

Figure 5. Global Knowledge Management Framework (GKMF) (Pawlowski \& Bick, 2012)

\section{Discussion}

\subsection{Knowledge Management (KM) Critical Success Factors (CSFs)}

In any concept, a huge gap often exists between theory and actual implementation: with KM being a more complex concept, this is even more valid. Many scholars over the last few years have identified this gap, with various studies, in particular, investigating critical success factors (CSFs). For example, researchers have utilized the processes, intellectual capital, culture, and strategy (PICS) model of Bhatti, Zaheer, and Rehman (2011), as originally proposed by Chong and Choi (2005), in an attempt to structure and add more rigor to their KM research.

Interestingly, in comparing the PICS model components with those in Table 3 below, what is noticeable is the overlap with the dimensions of KM CSFs as classified by KM scholars. The classifications in Table 3 were aligned and aggregated by this paper's author. For example, culture, national culture, and organizational culture were clustered into one classification, namely, culture. This serves to strengthen the argument that the most relevant and important CSFs in KM are those identified here. Three of the four factors stand out, namely, process, culture, and strategy, and thus should be considered as high-impact CSFs for KM implementation. All these factors are significantly influenced by the ways that people interact with them. 
Table 3. Critical success factors (CSFs) for knowledge management (KM)

\begin{tabular}{|l|l|l|}
\hline \multicolumn{3}{|l|}{ Critical Success Factors (CSFs) } \\
\hline $\begin{array}{l}\text { 1) Strategy/Purpose } \\
\text { (KM)/Organizational }\end{array}$ & $\begin{array}{l}\text { (2) Leadership/Management } \\
\text { Support/Commitment }\end{array}$ & $\begin{array}{l}\text { (3) Culture (KM/ } \\
\text { Organizational) }\end{array}$ \\
\hline $\begin{array}{l}\text { Arthur Andersen Business } \\
\text { Consulting and APQC (1996) }\end{array}$ & $\begin{array}{l}\text { Arthur Andersen Business } \\
\text { Consulting and APQC (1996) }\end{array}$ & $\begin{array}{l}\text { Arthur Andersen Business } \\
\text { Consulting and APQC (1996) }\end{array}$ \\
\hline & Davenport and Prusak (1998) & Davenport and Prusak (1998) \\
\hline Liebowitz (1999) & O'Dell and Grayson (1998) & O’Dell and Grayson (1998) \\
\hline Nelson and Middleton (2003) & Liebowitz (1999) & \\
\hline Wong (2005) & & Nelson and Middleton (2003) \\
\hline & Wong (2005) & Wong (2005) \\
\hline Conley and Zheng (2009) & Chong and Choi (2005) & Chong and Choi (2005) \\
\hline Al-Hakim and Hassan (2012) & Conley and Zheng (2009) & Conley and Zheng (2009) \\
\hline & Al-Hakim and Hassan (2012) & Al-Hakim and Hassan (2012) \\
\hline $\begin{array}{l}\text { (4) Structure/Process } \\
\text { (Infrastructure/Architecture) }\end{array}$ & Critical Success Factors (CSFs) & \\
\hline & (5) Technology (IT System) & $\begin{array}{l}\text { (6) Measuring Benchmarking } \\
\text { (Reward/Recognition) }\end{array}$ \\
\hline Davenport and Prusak (1998) & Arthur Andersen Business & $\begin{array}{l}\text { Arthur Andersen Business } \\
\text { Consulting and APQC (1996) }\end{array}$ \\
\hline & Consulting and APQC (1996) & Davenport and Prusak (1998) \\
\hline Liebowitz (1999) & & O’Dell and Grayson (1998) \\
\hline Nelson and Middleton (2003) & Liebowitz (1999) & Liebowitz (1999) \\
\hline Wong (2005) & Wong (2005) & Wong (2005) \\
\hline Chong and Choi (2005) & Chong and Choi (2005) & Chong and Choi (2005) \\
\hline Conley and Zheng (2009) & Conley and Zheng (2009) & Conley and Zheng (2009) \\
\hline Al-Hakim and Hassan (2012) & Al-Hakim and Hassan (2012) & \\
\hline & & \\
\hline
\end{tabular}

In parallel, when looking across to the general field of business management studies, another landmark study, called the "Evergreen Project," comes to mind (Nohria, Joyce, \& Roberson, 2003). In this longitudinal study (from 1986-1996) published in the Harvard Business Review, the research team sought common management practices that were successful in their investigation of 160 companies, with their work leading to the "What really works $4+2$ formula."

Interestingly, some overlap of factors was found, with the dimensions in Table 3 and the three primary management practices described in the Evergreen Project being the same, that is, strategy, culture, and structure. In terms of secondary practices, the identification of leadership by the Evergreen Project seems to support the suggested importance of the corresponding CSF "leadership/management support/commitment" in Table 3 above.

It is obvious that everything starts (or cascades) from strategy: to be more precise, the prior sequence should be vision, mission, and then strategy. Firstly, if company strategy prescribes the use of KM, that, in turn, should ensure provision (e.g., resources, development, know-how, etc.) necessary for implementation. Secondly, the right (positive) culture will guarantee a conducive environment and enable the implementation process whereas, on the 
other hand, a poisonous culture would be a barrier. Thirdly, structure is the guideline or framework that forces the process into a system. This is important for a team to hold onto if the change process becomes unclear or if they are distracted from their aim.

\subsection{General Knowledge Management (KM) Research in Recent Years}

This literature review consists of four parts: firstly, the review concept (see Figure 1 above) was depicted to show and explain how this review was organized. Secondly, an overview and the evolution of KM literature were provided (from the early 1990s-early 2000s). Thirdly, publications were reviewed commencing with the most recent (general) KM followed by hotel sector-specific KM.

As KM scholars and practitioners have voiced their concerns about the difficulty of measuring KM, seven papers (see Table 4 below) were reviewed, all of which have linkages to performance.

Table 4. Linkages to performance

\begin{tabular}{|c|c|c|c|}
\hline Author & Subject & Method & Summary \\
\hline Tseng (2016) & $\begin{array}{l}\text { Effect of KM } \\
\text { customer knowledge } \\
\text { gaps (CKGs) on } \\
\text { corporate } \\
\text { performance }\end{array}$ & Quantitative & $\begin{array}{l}\text { Investigating and linking KM capability (KMC) and } \\
\text { CKGs and the impact on company performance; } \\
\text { KMC has a significant effect on corporate } \\
\text { performance and firms with superior KMC } \\
\text { significantly reduce CKGs. }\end{array}$ \\
\hline $\begin{array}{l}\text { Wu and Chen } \\
(2014)\end{array}$ & $\begin{array}{l}\text { Knowledge } \\
\text { management- } \\
\text { driven firm } \\
\text { performance }\end{array}$ & Quantitative & $\begin{array}{l}\text { Aim was to find a model to properly evaluate KM } \\
\text { value. They considered operational excellence, } \\
\text { product leadership, customer intimacy, and financial } \\
\text { achievement as the performance indicators. }\end{array}$ \\
\hline $\begin{array}{l}\text { Kim, Lee, Chun, } \\
\text { and } \quad \text { Benbasat } \\
(2014)\end{array}$ & $\begin{array}{l}\text { Effect of } \\
\text { strategies } \\
\text { performance }\end{array}$ & Quantitative & $\begin{array}{l}\text { Drawing on a knowledge-based view, two } \\
\text { dimensions were identified: knowledge type and } \\
\text { origin, as well as four measurement approaches: } \\
\text { external codification, internal codification, external } \\
\text { personalization, and internal personalization. A KM } \\
\text { strategy was applied based on a technological, } \\
\text { organizational, environmental framework. For a KM } \\
\text { strategy to be successful, organizations must } \\
\text { consider internal and external factors }\end{array}$ \\
\hline $\begin{array}{l}\text { Jayasingam, } \\
\text { Ansari, Ramayah, } \\
\text { and Jantan (2013) }\end{array}$ & $\begin{array}{l}\text { KM practices and } \\
\text { performance (linkage) }\end{array}$ & Quantitative & $\begin{array}{l}\text { KM practices and KM project performance were } \\
\text { studied in } 180 \text { knowledge-based companies in } \\
\text { Malaysia with empirical proof of KM practice and } \\
\text { KM success. Differences between small and large } \\
\text { companies were noted. }\end{array}$ \\
\hline $\begin{array}{l}\text { Rašula, Vukšić, } \\
\text { and Štemberger } \\
(2012)\end{array}$ & $\begin{array}{l}\text { Impact of } \mathrm{KM} \text { on } \\
\text { organizational } \\
\text { performance }\end{array}$ & Quantitative & $\begin{array}{l}\text { This paper claims that through creating, } \\
\text { accumulating, organizing, and utilizing knowledge, } \\
\text { organizations can enhance organizational } \\
\text { performance. The results show that KM practices can }\end{array}$ \\
\hline
\end{tabular}




\begin{tabular}{|l|l|l|l|}
\hline & & & positively affect organizational performance. \\
\hline $\begin{array}{l}\text { Andreeva and } \\
\text { Kianto (2012) }\end{array}$ & $\begin{array}{l}\text { Linking } \\
\text { practices, } \\
\text { competitiveness, and } \\
\text { economic } \\
\text { performance }\end{array}$ & $\begin{array}{l}\text { Quantitative } \\
\text { innovation, } \\
\text { performance }\end{array}$ & $\begin{array}{l}\text { Findings: HRM and ICT practices have a statistically } \\
\text { significant influence on a firm's financial } \\
\text { performance and competitiveness. Their study also } \\
\text { indicated that, if coupled with HRM practices, } \\
\text { financial performance is improved by ICT practices. }\end{array}$ \\
\hline $\begin{array}{l}\text { López-Nicolás and } \\
\text { Meroño-Cerdán }\end{array}$ & $\begin{array}{l}\text { Quantitative } \\
\text { (2011) }\end{array}$ & $\begin{array}{l}\text { Aim was to shed light on the consequences of KM } \\
\text { strategies on a firm's innovation and corporate } \\
\text { performance. Their research found that strategic KM } \\
\text { improves organizational performance } \\
\text { innovation, and explained how. }\end{array}$ \\
\hline
\end{tabular}

Initially, one would expect that the reviewed papers would follow a similar train of thought as the titles were similar (all had two words in common: knowledge management [KM] and performance).

However, the most recent paper by Tseng (2016) seemed to look at a new direction in KM research. The author explained and differentiated two categories of corporate performance measure: knowledge management capability (KMC) and customer knowledge gap (CKG). The author argued for a strong link between $\mathrm{KMC}$ and $\mathrm{CKG}$, with this link suggesting that improved $\mathrm{KMC}$ and a reduced $\mathrm{CKG}$ will have a significant effect on performance. A similarity in approach was apparent when Wu and Chen (2014) also came up with a twofold classification: (1) knowledge assets and (2) knowledge process capability. Within Tseng's (2016) KM capability, dimensions were based on the knowledge cycle (i.e., the acquire, transfer, and distribute model), whereas Wu and Chen (2014) used a four-factor cycle of creation, transfer, integration, and application. However, Kim et al. (2014) based their research on knowledge type and origin. Their study defined four KM strategies: external codification, internal codification, external personalization, and internal personalization. These were tied to a contingency framework that identified technology-organizationenvironment and key factors. Conversely, Wu and Chen (2014) considered knowledge resources and process capabilities as important, seeing a critical link between these two dimensions and organizational learning.

Another KM perspective was introduced by Andreeva and Kianto (2012) who considered its HRM and ICT aspects. In Jayasingam et al.'s (2013) quantitative study of 180 knowledge-based companies in Malaysia, empirical proof was found for the success of firms with KM practices. Furthermore, Rašula et al. (2012) based their study on a construct of three critical dimensions: (1) information technology (IT) (the ability of technology to capture knowledge and the usage of information systems [IS]); (2) organization (people, organizational climate, and processes); and (3) knowledge (knowledge accumulation and utilization, sharing practices, and knowledge ownership identification). In another study, López-Nicolás and Meroño-Cerdán (2011) investigated KM strategies (considering the 
aspects of codification and personalization) and linked them to innovation and performance, providing empirical proof that strategic KM improves performance and innovation. To harmonize and equalize the research approach and methodology, it would be worthwhile to attempt to integrate the concepts of these papers, thus enabling KM to be measured in a common and comparable way.

This research highlights the significant ongoing evolution of KM ideas, models, and concepts outside of the hotel industry. However, as highlighted in the current literature review, finding much published research on KM inside the hotel industry is difficult. In the next subsection, the reason why this may be the case becomes the focus.

\subsection{What is the Status of Hotel (Hospitality)-Specific Knowledge Management (KM)?}

Due to the lack of (pure) hotel-specific (KM) research, Cheng's (2010) comprehensive (KM) literature review (hospitality/tourism-centric) was used as an auxiliary source and a reference point from which to paint an overall picture of where (hotel) KM stands. In his review, Cheng (2010) suggested that scholars should improve methodological rigor and use a wider base for their research so the findings (results) will be more reliable. Consequently, KM will become easier for practitioners and policy makers to understand and implement. With that in mind, the most recent KM literature was reviewed and discussed in the current study.

Owing to the lack of hotel sector-specific papers, the review is limited to the studies outlined in Table 5:

Table 5. Papers on hotel sector-specific knowledge management (KM)

\begin{tabular}{|l|l|l|}
\hline Author & Subject & Method \\
\hline Salem (2014) & KM in 5-star chain hotels in Egypt & Quantitative (survey) \\
\hline $\begin{array}{l}\text { Wong, Wickham, and } \\
\text { Hall (2013) }\end{array}$ & $\begin{array}{l}\text { The paradox of training and development: Knowledge } \\
\text { management in the Chinese hospitality industry context }\end{array}$ & $\begin{array}{l}\text { Qualitative (survey } \\
\text { and interview) }\end{array}$ \\
\hline Mahapa (2013) & Impact of KM on performance of hotels in Zimbabwe & $\begin{array}{l}\text { Qualitative (case } \\
\text { study and survey) }\end{array}$ \\
\hline $\begin{array}{l}\text { Isa, Abdullah, Hamzah, } \\
\text { and Arshad (2008) }\end{array}$ & Intellectual capital and KM: Malaysian hotels & $\begin{array}{l}\text { Qualitative (multiple } \\
\text { case study) }\end{array}$ \\
\hline
\end{tabular}

Considering the titles and subsequent foci of the above-listed studies, the argument that hotel sector-specific KM is sparse, and that KM is still in its infancy in this sector, appears to be supported.

Although, on the surface, all four papers appear to research the same subject (hotel KM), they all bear significant gaps and have differences in foci and rigor. Even though Serenko (2013) reported strong development in (general) KM literature, the KM literature with a hotel sector-specific focus (e.g., hotel-centric papers) appears to be lacking, as suggested by Salem (2014) and Bouncken (2002). It is unclear whether this is a result of the hotel industry being unaware of trends, or due to a lack of researchers interested in investigating hotel sector-specific $\mathrm{KM}$, or the possibility that knowledge is considered as a competitive advantage, and therefore not published (or perhaps elements of all three). 
Besides the obvious differences of the above papers in terms of method, geographic location, and size of sample, unifying factors were also found. All four papers conveyed a very positive view of KM, and all indicated similar benefits (e.g., competitive advantage, more innovation, and better performance). In addition to the previously reported lack of published work on KM evolution and trends, Serenko (2013), who researched 108 scientometric studies, had a similar observation about KM's general body of knowledge. As neither a unified framework nor a commonly agreed terminology has been developed, it is rather difficult to find a good foundation for KM research.

On one hand, it is encouraging that Salem (2014) conducted a quantitative study as most (hotel) KM papers have used the qualitative method. His study also has weight relevance as the sample size was quite significant. On the other hand, many authors have preferred and justified the use of qualitative research (and mostly, the case study approach) as this is regarded as research in a specific context. When exploring KM with people responsible for its application, authors have found that the qualitative method is better suited.

A key concern about all four studies was their geographic restriction (to one country only), with even greater concern about the level at which the research was undertaken. Typically, hotel companies strategize and decide actions and direction in the head office. Taking, for example, the research by Wong, Wickham, and Hall (2013) (and this could also be said of the other studies), a justified concern would be the selection of participants from the property level. It could be argued that, while Parkyard Hotels has a fantastic KM program/framework that is used at headquarters and across its portfolio, the researched hotel (as the only one in the group) either missed out on (or was delayed in) implementing the program. Another important issue would be size and star rating. For example, Marriott International (<statista.com>) (with over 6,000 hotels worldwide) and Dusit International (<dusit.com>) with 25 hotels (mostly in South East Asia) operate differently (in terms of resources, strategy, processes, structure, financial backing, etc.). Of the above four papers, only Salem (2014) seemed to consider the hotel star rating category (but only 5-star chain hotels) even if no explicit explanation was provided for why they were chosen and not others (e.g., 3-star or 4-star). Among these authors, Mahapa (2013) seemed to be least concerned as she selected three hotels (with no mention of brand affiliation or rating) which could cause distortion in the findings.

However, both Salem (2014) and Mahapa (2013) understood that using a construct would provide more clarity and structure. Furthermore, Salem (2014, citing Lee \& Choi, 2003) identified four variables, namely, technology, structure, culture, and human resources. Similarly, Mahapa (2013, citing Bhatti et al., 2011), as proposed in Chong and Choi (2005), applied the PICS model (process, intellectual capital, culture, and strategy). These papers indicated that while some hotels are interested in implementing KM elements, KM practices are limited and not widespread in the hotel industry. This highlights the possible opportunity to introduce more $\mathrm{KM}$ practices across more organizations in this sector to enhance organizational performance. 
5.4 What are the More Recent Trends in Hotel Knowledge Management (KM)?

Based on the current review, KM is believed to be very much alive and can be considered as a well-respected management concept, although evidence for its adoption by the hotel industry is not available. Hotel enterprises (and any other business) and their leadership could use $\mathrm{KM}$ as a tool to gain efficiency and competitive advantage, but the hotel industry does not seem to be adopting this approach. The notion of disparity, the absence of uniform terminology, and the lack of a defined focus are supported by the above findings. Perhaps, these factors could be influencing the lack of uptake. This stance is supported by the 25 years of experience of this paper's author working in the hotel industry. Through his employment in large and small hotel companies, he has observed that only very large multinational hotel companies (e.g., Marriott, InterContinental Hotels Group [IHG], Accor, etc.) use some sort of KM programs and technology and implement and/or enforce them. Despite the lack of available hotel sector-specific research, the use of KM by hotel companies is clearly indicated. Looking at the soft (human) side of $\mathrm{KM}$, indications of $\mathrm{KM}$ practices in large hotel companies include their employment of people to drive KM initiatives. For example, IHG employs an Analyst, Knowledge Management and a Knowledge Management \& Sharing Culture Champion (<kmworld.com $>$ ), while the Hilton employs a Chief Learning Officer [CLO] (<businesschampions.org>). In parallel, on the hard (technology) side of KM, indications of KM implementation include all major hotel companies having an intranet portal (e.g. Marriott's intranet portal is called Marriott Global Sources <mgs.marriott.com>; IHG's portal is called IHG Merlin <me2.ihgmerlin.com>; Accor's portal is called MyAccor Hotels <apps.myaccorhotels.com>; while the Hilton's portal is The Lobby $<$ lobby.hilton.com>). All these portals have similar features (best practice repository, learning center, news, updates and information, lessons learned, etc.). All the large hotel companies have KM-related programs but they may call KM activities by different names (e.g., operational excellence, global learning, process improvement, etc.).

The above discussion shows that hotel companies are committed (in terms of financial and other resources) to knowledge management (KM). However, as previously mentioned, hotel sector-specific KM research is poor in quantity and inconsistent in quality. One reason for less research in this specific field could be the weak link between the hotel industry and research (Cooper [2006] lamented the weak KM research agenda in hospitality and tourism [author's remark - that includes the hotel industry]). In addition, very little information can be found on the internet with the following reasons among the assumptions:

1) Hotel companies want to protect their competitive advantage and do not want to share (disclose) any information.

2) They practice KM (or elements of it) but they do not call it by this name (they are not aware that it is $\mathrm{KM})$.

3) They do not use or know about KM.

4) Their KM looks different (it may be called "digital strategy") For example, on the technological/IT side of KM, ACCOR refers to digitalization (<hotelnewsnow.com>) as 
they have moved onto the "next-generation KM" (e.g., enterprise social media, crowdsourcing, etc.).

Very recently, an article published on Skift (<skift.com>) announced one of the Marriott's latest application (app) developments. This app uses machine learning and artificial intelligence (AI) to learn from the guest (user) (by collecting information posted on social media, shared locations, and interaction patterns) in order to make suggestions to the guest (user) about Marriott hotels (offerings and services) and to drive engagement. That news article and Accor's plans (<webzine-actionnaires.accorhotels-group.com>) to transform the company into a digital business are the latest indications of KM's existence in the hotel sector, demonstrating the keen interest of hotel companies in evolving technologies further and developing strategies for competitive advantage.

\section{Conclusion}

In summary, this paper has introduced and explained the fundamentals of KM and explained its history and evolution, followed by a review of recent HKM literature. It is understood that $\mathrm{KM}$ is a widely dispersed and complex phenomenon across several industries; however, to date, KM has no uniform model, terminology, or research focus. As a result, research on hotel $\mathrm{KM}$ is still in its infancy. This highlights an important opportunity to conduct basic-level hotel KM research to clarify the benefits (with this paper providing some contribution at this level) before moving to more complex research on the sophisticated ways in which HKM can address the more complex challenges facing the hotel sector. The dispersed nature of current HKM research and the lack of focus make it hard to narrow down to the best options and to progress the research agenda. A unified and focused research agenda is important for progress in any research field. It is therefore believed that this paper helps, to some degree, to provide a better understanding and, hopefully, to initiate renewed interest from academia and industry in the hotel-specific KM field.

In the process of completing this paper, it became evident that hotel sector-specific KM (HKM) is in its infancy. The available studies either look at only one aspect of KM or collect and analyse data collected (by questionnaire) from hotel company employees. However, as stated above, most employees (possibly 90\%) have never come across the term "knowledge management (KM)" and are completely unaware of the term "hotel sector-specific knowledge management (HKM)" (a parallel would be asking an apprentice mechanic about engine dynamics and performance optimization). It is highly doubtful that these data are useful or valid for further insight and research. It is hoped that future HKM research will look at industry cases (revelatory studies) to see how HKM is applied in the actual industry context. Moreover, it is hoped that the hotel industry and research community will connect with each other to advance the depth of HKM research. For additional validation and rigor, it is hoped that future research will include quantitative and mixed-methods research approaches, and that it will expand by undertaking cross-country studies, and studies of small and large hotel companies, as well as longitudinal studies. 


\section{References}

Abel, A., \& Oxbrow, N. (2001). Competing with knowledge: The information professional in the knowledge management age. London: Library Association Publishing.

Al-Hakim, L. A. Y., \& Hassan, S. (2012). Critical success factors of knowledge management, innovation and organisational performance: An empirical study of the Iraqi mobile telecommunication sector. British Journal of Economics, Finance and Management Sciences, $4,31-49$.

Andreeva, T., \& Kianto, A. (2012). Does knowledge management really matter? Linking knowledge management practices, competitiveness and economic performance. Journal of Knowledge Management, 16, 617-636.

Arrow, K. J. (1962). The economic implications of learning by doing. Review of Economic Studies, 29, 155-173.

Arrow, K. J. (1969). Classificatory notes on the production and transmission of technological knowledge. American Economic Review, 59, 29-35.

Arrow, K. J. (1974). The limits of organization. New York: W. W. Norton.

Arthur Andersen Business Consulting \& American Productivity and Quality Center (APQC) (1996). Knowledge management: Consortium benchmarking study. Final report.

Bassi, L. J. (1997). Harnessing the power of intellectual capital. Training and Development Journal, 51, 25-31.

Becerra-Fernandez, I., \& Sabherwal, R. (2014). Knowledge management: Systems and processes. Routledge, Taylor \& Francis Group.

Bhatti, W. A., Zaheer, A., \& Rehman, K. U. (2011). The effect of knowledge management practices on organizational performance: A conceptual study. African Journal of Business Management, 5, 2847-2853.

Blackler, F. (1995). Knowledge, knowledge work and organizations: An overview and interpretation. Organization Studies, 16, 1021-1046.

Blumentritt R., \& Johnston, R. (1999). Towards a strategy for knowledge management. Technology Analysis \& Strategic Management, 11, 287-300.

Bouncken, R. B. (2002). Knowledge management for quality improvements in hotels. Journal of Quality Assurance in Hospitality \& Tourism, 3, 25-59.

Cawthorne, J. (2009). [Online] Available:

http://ecm-stuff.blogspot.com/2009/02/where-ecm-fits-in-bigger-information.html

Cheng, X. (2010). Management research in the hospitality and tourism industry. UNLV [University of Nevada, Las Vegas] Theses, Dissertations, Professional Papers, and Capstones, 762. [Online] Available: https://digitalscholarship.unlv.edu/thesesdissertations/762 


\section{Macrothink}

Business and Economic Research

ISSN 2162-4860

2019, Vol. 9, No. 2

Chong, S. C., \& Choi, Y. S. (2005). Critical factors of knowledge management implementation success. Journal of Knowledge Management Practice, 6, 21-37.

Choo, C. W. (1996). The knowing organization: How organizations use information to construct meaning, create knowledge and make decisions. International Journal of Information Management, 16, 329-340.

Collins, H. M. (1993). The structure of knowledge. Social Research, 60, 95-116.

Conley, C. A., \& Zheng, W. (2009). Factors critical to knowledge management success. In Advances in developing human resources, 11, 334-348.

Cooper, C. (2006). Knowledge management and tourism. Annals of Tourism Research, 33, 47-64.

Dalkir, K., \& Liebowitz, J. (2011). Knowledge management in theory and practice. MIT Press.

Davenport, T. H., \& Prusak, L. (1998). Working knowledge: How organizations manage what they know. Harvard Business Press.

Dixon, N. (2012). The three eras of knowledge management. Weblog

<http://www.nancydixonblog.com/2012/08/the-three-eras-of-knowledge-management.html>, accessed May 9, 2017.

Drucker, P. (2001). The next society. The Economist, 52.

Duhon, B. (1998). It's all in our heads. Inform, 12, 8-13.

Duru, O. (2014). [Online] Available: http://www.okanduru.com/becon.htm

European Committee for Standardization (Comité Européen de Normalisation [CEN]) (2004). European guide to good practice in knowledge management. CWA [CEN workshop agreement] 14924 Parts 1-5. Brussels: European Committee for Standardization.

Fleck, J. (1997). Contingent knowledge and technology development. Technology Analysis \& Strategic Management, 9, 383-397.

Frantz, A., Inghilleri, L., Mene, P., Schultenover, J., Schulze, H., \& Warman, B. (2000). The Ritz-Carlton Hotel Company: 1992 and 1999 Malcolm Baldrige Quality Award Winner, Journal of Innovative Management, Fall, 3-30.

Gold, A. H., Malhotra, A., \& Segars, A. H. (2001). Knowledge management: An organizational capabilities perspective. Journal of Management Information Systems, 18, 185-214.

Gray Southon, F. C., Todd, R. J., \& Seneque, M. (2002). Knowledge management in three organizations: An exploratory study. Journal of the Association for Information Science and Technology, 53, 1047-1059.

Hallin C. A., \& Marnburg, E. (2008). Knowledge management in the hospitality industry: A review of empirical research. Tourism Management, 29, 366-381. 
Heisig, P. (2009). Harmonisation of knowledge management - Comparing $160 \mathrm{KM}$ frameworks around the globe. Journal of Knowledge Management, 13, 4-31.

Hibbard, J. (1997). Knowing what we know. InformationWeek, 653, 46-64.

Hu, M.-L. M., Horng, J.-S., \& Sun, Y.-H. C. (2009). Hospitality teams: Knowledge sharing and service innovation performance. Tourism Management, 30, 41-50.

Ihrig, M., \& MacMillan, L. (2015). Managing your mission-critical knowledge. Harvard Business Review, 93, 80-87.

International Organization for Standardization (ISO) (2019). ISO 30401 Knowledge Management Standard.

Isa, R. M., Abdullah, N. L., Hamzah, N., \& Arshad, R. (2008). The typology of intellectual capital and knowledge management in Malaysian hotel industry. Journal of Human Resource and Adult Learning, 4, 103-114.

Jashapara, A. (2005). The emerging discourse of knowledge management: A new dawn for information science research? Journal of Information Science, 31, 136-148.

Jayasingam, S., Ansari, M. A., Ramayah, T., \& Jantan, M. (2013). Knowledge management practices and performance: Are they truly linked? Knowledge Management Research \& Practice, 11, 255-264.

Kim, T. H., Lee, J.-N., Chun, J. U., \&. Benbasat, I. (2014). Understanding the effect of knowledge management strategies on knowledge management performance: A contingency perspective, Information \& Management, 51, 398-416.

Knapp E. M. (1998). Knowledge management. Business and Economic Review, 44, 3-6.

Lambe, P. (2011). The unacknowledged parentage of knowledge management. Journal of Knowledge Management, 15, 175-197.

Lave, E. J. (1991). Situating learning in communities of practice. Chapter 4 in L. B. Resnick, J. M. Levine, \& S. D. Teasley (Eds.), Perspectives on socially shared cognition. vol. 5, no. 2, Washington, DC: American Psychological Association, pp. 63-82.

Lee, H., \& Choi, B. (2003). Knowledge management enablers, processes, and organizational performance: An integrative view and empirical examination. Journal of Management Information Systems, 20, 179-288.

Leonard-Barton, D. (1995). Wellsprings of knowledge: Building and sustaining the sources of innovation. Boston, MA: Harvard Business School Press.

Liebowitz, J. (1999). Key ingredients to the success of an organization's knowledge management strategy. Knowledge and Process Management, 6, 37-40.

Liebowitz, J., \& Beckman, T. (1998). Knowledge organizations: What every manager should know. Boca Raton, FL: St. Lucie Press/CRC Press. 


\section{Macrothink}

Business and Economic Research ISSN 2162-4860 2019, Vol. 9, No. 2

Liebowitz, J., \& Wilcox, L. C. (1997). Knowledge management and its integrative elements. CRC Press.

López-Nicolás, C., \& Meroño-Cerdán, Á. L. (2011). Strategic knowledge management, innovation and performance. International Journal of Information Management, 31, 502-509.

Lundvall, B.-A. (1996). The social dimension of the learning economy. DRUID [Danish Research Unit for Industrial Dynamics] Working Paper, No. 1, Department of Business Studies, Aalborg University.

Machlup, F. (1962). The production and distribution of knowledge in the United States. Princeton University Press.

Magnier-Watanabe, R., \& Senoo, D. (2008). Organizational characteristics as prescriptive factors of knowledge management initiatives. Journal of Knowledge Management, 12, 21-36. https://doi.org/10.1108/13673270810852368

Mahapa, M. (2013). Impact of knowledge management strategies on organizational performance in the hospitality industry of Zimbabwe. Public Administration Review, 2, 76-83.

Maier, R. (2007), as cited in Maier, R. \& Schmidt, A. (2007). Characterizing knowledge maturing: A conceptual process model for integrating e-learning and knowledge management. In Proceedings of the 4th Conference of Professional Knowledge Management (WM 2007). Experiences and Visions, Potsdam, Germany, pp. 325-333.

Merriam Webster. [Online] Available: learnersdictionary.com

Millar, J., Demaid, A., \& Quintas, P. (1997). Transorganizational innovation: A framework for research. Technology Analysis \& Strategic Management, 9, 399-418.

Nelson, K., \& Middleton, M. (2003). An exploratory analysis of information and knowledge management enablers in business contexts. In E. Coakes (Ed.), Knowledge management: Current issues and challenges. Hershey, PA: IRM Press, pp. 104-115.

Nohria, N., Joyce, W. F., \& Roberson, B. (2003). What really works. Harvard Business Review, $81,43-52$.

Nonaka, I. (1991). The knowledge creating company. Harvard Business Review, 69, 96-104.

O’Dell, C., \& Grayson, C. J. (1998). If only we knew what we know: Identification and transfer of internal best practices. California Management Review, 40, 154-174.

Pawlowski, J., \& Bick, M. (2012). The Global Knowledge Management Framework: Towards a theory for knowledge management in globally distributed settings. Electronic Journal of Knowledge Management, 10, 92-108. Available online at <www.ejkm.com> or at <http://users.jyu.fi/ japawlow/GKMF_Pawlowski_Bick_EJKM2012citation.pdf>.

Petrash, G. (1996). Dow's journey to a knowledge value management culture. European Management Journal, 14, 365-373.

Polanyi, M. (1966). The tacit dimension. Garden City, NY: Doubleday and Co. 
Rašula, J., Vukšić, V. B., \& Štemberger, M. I. (2012). The impact of knowledge management on organisational performance. Economic and Business Review, 14, 147-168.

Ricca, S. (2018). Global Hotel Industry M\&A List. [Online] Available:

http://www.hotelnewsnow.com/Articles/71864/HNNs-global-hotel-industry-MandA-list

Salem, I. E.-B. (2014). Toward better understanding of knowledge management: Correlation to hotel performance and innovation in five-star chain hotels in Egypt. Tourism and Hospitality Research, 14, 176-196.

Serenko, A. (2013). Meta-analysis of scientometric research of knowledge management: Discovering the identity of the discipline. Journal of Knowledge Management, 17, 773-812.

Shelley, A. W. (2007). Knowledge-Driven Performance course.

Shelley, A. W. (2009). Being a successful knowledge leader: What practitioners need to know to make a difference. North Sydney: ARK Publishing.

Shelley, A. W. (2017). KNOWledge SUCCESSion: Sustained performance and capability growth through strategic knowledge projects. New York, NY: Business Expert Press.

Sigala, M., \& Chalkiti, K. (2007). New service development: Preliminary findings on process development and assessment from the Greek hotels. In Advances in hospitality and leisure, Emerald Group Publishing Limited.

Statista (2017). Total Revenue of the Global Hotel Industry. [Online] Available:

https://www.statista.com/topics/1102/hotels

Tseng, S.-M. (2016). The effect of knowledge management capability and customer knowledge gaps on corporate performance. Journal of Enterprise Information Management, $29,51-71$.

Voegeli, C. (2015). [Online] Available:

http://ehotelier.com/insights/2015/09/30/why-knowledge-management-matters-to-the-hotel-i ndustry

Wenger, E. (1998). Communities of practice: Learning, meaning, and identity (Learning in doing: Social, cognitive and computational perspectives). New York: Cambridge University Press.

Wiig, K. M. (1993). Knowledge management foundations: Thinking about thinking - How people and organizations create, represent, and use knowledge. Arlington, TX: Schema Press.

Wiig, K. (1997a). Knowledge management: An introduction and perspective. Journal of Knowledge Management, 1, 6-14.

Wiig, K. M. (1997b). Knowledge management: Where did it come from and where will it go? Expert Systems with Applications, 13, 1-14. 


\section{Macrothink}

Business and Economic Research ISSN 2162-4860 2019, Vol. 9, No. 2

Williams, D. (2014). Models, metaphors and symbols for information and knowledge systems. In D. Lambe (Ed.), Knowledge Management Special Issue: Connecting Theory and Practice, 10, pp. 79-108.

Williams, D. (2015). Nuts and bolts of a knowledge management system. Journal of Information \& Knowledge Management, 14. https://doi.org/10.1142/S0219649215500355

Wong, K. Y. (2005). Critical success factors for implementing knowledge management in small and medium enterprises. Industrial Management and Data Systems, 105, 261-279.

Wong, T., Wickham, M., \& Hall, L. (2013). The paradox of training and development: Knowledge management in the Chinese hospitality industry context. Presented at the $27^{\text {th }}$ Annual Australian and New Zealand Academy of Management (ANZAM) Conference, Hobart, Tasmania.

Wu, I. L., \& Chen, J. L. (2014). Knowledge management driven firm performance: The roles of business process capabilities and organizational learning. Journal of Knowledge Management, $18,1141-1164$.

Yang, J.-T. (2007). Knowledge sharing: Investigating appropriate leadership roles and collaborative culture. Tourism Management, 28, 530-543.

Yang, J.-T. (2009). Individual attitudes to learning and sharing individual and organisational knowledge in the hospitality industry. Service Industries Journal, 29, 1723-1743.

Yang, J.-T. (2010). Antecedents and consequences of knowledge sharing in international tourist hotels. International Journal of Hospitality Management, 29, 42-52.

Yang J.-T., \& Wan, C.-S. (2004). Advancing organizational effectiveness and knowledge management implementation. Tourism Management, 25, 593-601.

\section{Websites}

Accor Webzine

$<\mathrm{http}$ ///webzine-actionnaires.accorhotels-group.com/en/article/35/Accor_launches_its_digital _transformation_leading_digital_hospitality.html)>.

Business Champions

$<$ http://businesschampions.org/kimo-kippen-of-hilton-worldwide-named-chief-learning-offic er-of-the-year/>.

Dusit International <www.dusit.com/about-us/>.

Hotelnewsnow.com

$<$ http://www.hotelnewsnow.com/Articles/290231/6-ways-AccorHotels-is-transforming-its-di gital-strategy>.

Intercontinental Hotels Group (IHG) Merlin <https://me2.ihgmerlin.com>.

KMWorld <http://www.kmworld.com/Conference/Speakers/Ilene-Strongin-Garry.aspx>. 
Lobby (The), Hilton <https://lobby.hilton.com>.

Marriott Global Source <https://mgs.marriott.com>.

Marriott International, <www.marriott.com>.

MyAccor Hotels <https://apps.myaccorhotels.com>.

Skift

<https://skift.com/2017/02/13/what-marriott-learned-from-starwoods-loyalty-and-digital-exp ertise/>.

Statista.com

$<$ https://www.statista.com/statistics/247285/number-of-marriott-international-hotels-worldwi de/>

\section{Copyright Disclaimer}

Copyright for this article is retained by the author(s), with first publication rights granted to the journal.

This is an open-access article distributed under the terms and conditions of the Creative Commons Attribution license (http://creativecommons.org/licenses/by/3.0/). 